\title{
Oxford Handbook of Mary
}

Maunder, Chris, ed. Oxford Handbook of Mary. Oxford: Oxford University Press, 2019. 736 pp. \$150.00. Hardcover. ISBN: 9780198792550 . Also available electronically as a part of Oxford Handbooks Online. DOI: 10.1093/oxfordhb/9780198792550.001.0001.

The Oxford Handbook of Mary is a collection of forty-two essays which examine the effect Mary-a Jewish woman from an insignificant village within Roman-controlled Palestine-has had on believers throughout history via multiple lenses. The numerous authors of the essays have varied backgrounds, both scholastically and theologically. Many are Christians from across various denominations and roles. This enhances the unity and diversity regarding the role of Mary in living out a Christian faith. Muslim and Jewish authors are likewise represented, allowing the reader to note how Mary is seen in those religions. Anthropologists, artists, historians, and theologians in combination shine different lights upon Mary's identity. The editor arranged the essays into five sections that approximate the development of Christianity.

The first portion presents Mary from the Apostolic Age through the Great Schism. In this section, essays focus on Mary in the Christian Gospels and apocryphal writings, interpretations of these by numerous Church Fathers, and dogmatic presentations developed during the early Church Councils (431 and before). An essay dedicated to the role of Mary in Islam is also presented in this first part, as Islam came into being before the Great Schism of 1054.

The second section of essays in the Oxford Handbook of Mary focuses on how Mary is presented in the eastern Churches, picking up a division in Christianity that occurred as a result of the Great Schism of 1054. The focus of these contributions is the liturgical life of the Byzantine churches aligned with Constantinople, with special focus on Greek and Russian Orthodox understandings of Mary. These liturgical contributions include various hymns and homilies from significant figures in Greek Orthodoxy like Proklos, a fifth-century archbishop of Constantinople; Romanos the Melodist; and the monk and Marian visionary Gregorios Palamas. From the Russian tradition is a commentary on the works of Pyotr Bessanov, a nineteenth-century hymnist. The final essays in this section examine Marian devotion in the Eastern Church during our times, focusing on Finland, the eastern Mediterranean, Romania, and Russia.

After this exploration of the East, the journey moves to western Europe and is spread over the next two essay groups. The first set examines the life of Mary in the Roman Church from the Great Schism until the Reformation; the second from the Reformation to the current age. In certain essays, some authors examine a particular strand of Marian thought throughout both eras; other essayists focus solely on one timeframe. In these clusters, some writers have contributed works on Mary in the fine arts of the Western Churches. Others focus on the development of Marian doctrine in Anglicanism, Lutheranism, and Roman Catholicism. Further writers explore what Marian devotion looks like in Asia and the Americas, both within culture and within different religious traditions. Certain essays reflect on Marian devotion and how this helped and hindered women's growth.

In the final collection of essays, a major shift occurs in that the writers focus on Mary as less a theological figure and more a cultural icon. Authors examine Mary as a cultural icon by examining pilgrimages, miracles, and apparitions. The initial essays discuss the role of pilgrimages to Marian shrines with miracles, either healing or mystical. This theme of pilgrimage continues through ex- 
amining this devotion in light of multi-faith programs and migration as pilgrimage. Later essays in this group examine the modern-day phenomenon of Marian apparitions and how the messages are misappropriated to accommodate certain agendas that can be seen as fringe if not outright schismatic. While seemingly disparate, the articles on pilgrimages and apparitions are connected by the reactions of numerous devotees to Mary.

Certain weaknesses do appear in this volume. First, no chapter attempts to place Mary within her context as a poor Jewish woman and mother in Roman-controlled Palestine. An essay on this topic would have been an excellent starting point for this volume. Another weakness is that no exploration occurs in who Mary is in the Oriental Churches, whose history reaches to the Apostolic Age. This gap is disconcerting because, while these Christians may not be as well-known as their European counterparts, their contributions would have allowed exposure to how Mary is seen by these believers. The editor rightfully acknowledges that a single tome cannot adequately serve as a thorough book on Mary in the introduction, and these weaknesses reflect this statement.

Overall, this collection of essays is worthwhile for understanding how Mary has been viewed throughout time and place, as well as in a myriad of religious traditions and academic fields. Its transdisciplinary nature effectively moves Marian studies outside the sole realm of theologians and asks scholars in different fields to assist in sharing how Mary affects others. Creating new connections among diverse disciplines is a needed trend in academia, and the Oxford Handbook of Mary does this well. This book is highly recommended as an item that demonstrates current scholarship regarding trends in Marian studies.

Br. Andrew J. Kosmowski, SM

Librarian

North American Center for Marianist Studies

Dayton, $\mathrm{OH}$ 